\title{
THE ANALYSIS OF COMPETITION POLICY AND SECTORAL REGULATION
}




\title{
World Scientific-Now Publishers Series in Business
}

ISSN: 2251-3442

\author{
Vol. 1 Games and Dynamic Games \\ by Alain Haurie, Jacek B. Krawczyk and Georges Zaccour
}

Vol. 2 Dodd-Frank Wall Street Reform and Consumer Protection Act:

Purpose, Critique, Implementation Status and Policy Issues edited by Douglas D. Evanoff and William W. Moeller

Vol. 3 The History of Marketing Science

edited by Russell S. Winer and Scott A. Neslin

Vol. 4 The Analysis of Competition Policy and Sectoral Regulation edited by Martin Peitz and Yossi Spiegel 
World Scientific - Now Publishers Series in Business: Vol. 4

\section{THE ANALYSIS OF COMPETITION POLICY AND SECTORAL REGULATION

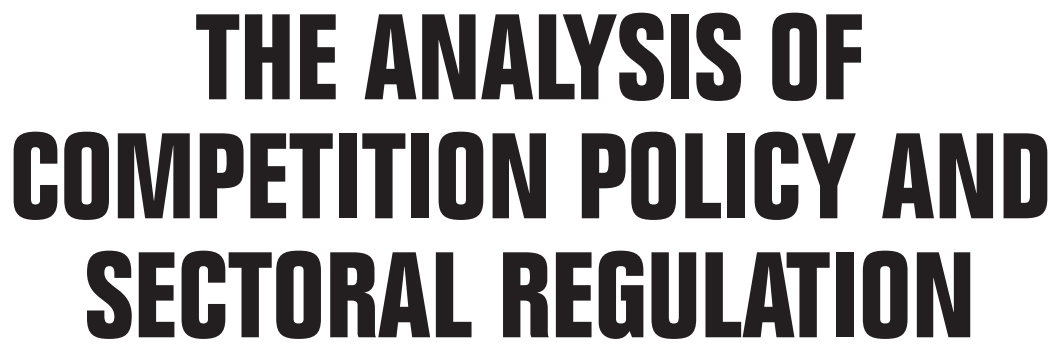

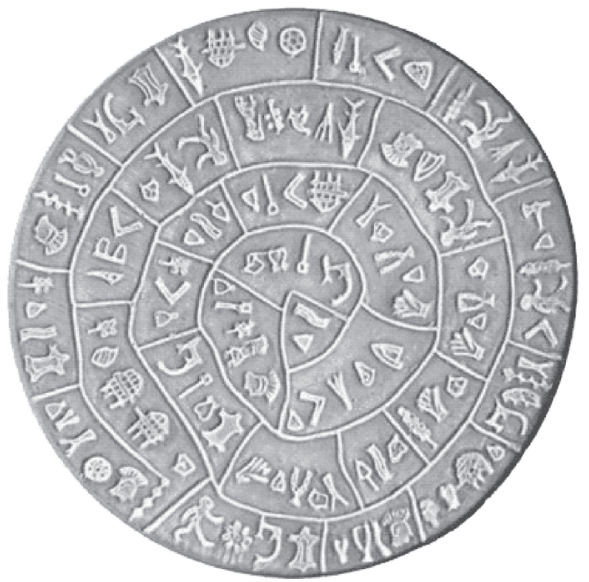

Editors

Martin Peitz

University of Mannheim, Germany \& CERRE

Yossi Spiegel

Tel Aviv University, Israel \& CEPR \& ZEW 


\section{Published by}

World Scientific Publishing Co. Pte. Ltd.

5 Toh Tuck Link, Singapore 596224

USA office: 27 Warren Street, Suite 401-402, Hackensack, NJ 07601

UK office: 57 Shelton Street, Covent Garden, London WC2H 9HE

and

now publishers Inc.

PO Box 1024

Hanover, MA 02339

USA

\section{Library of Congress Cataloging-in-Publication Data}

The analysis of competition policy and sectoral regulation / [edited] by Martin Peitz (Univ of

Manheim, Germany; MaCCI, \& CERRE) and Yossi Spiegel (Tel Aviv Univ, Israel; CEPR \& ZEW).

pages cm. -- (World Scientific-now publishers series in business, ISSN 2251-3442; v. 4)

Conference proceedings.

"This volume contains a selection of papers that were presented at the CRESSE Conferences held

in Chania, Crete, from July 6th to 8th, 2012, and in Corfu from July 5th to 7th, 2013."

Includes bibliographical references and index.

ISBN 978-9814616355 (alk. paper)

1. Competition--Congresses. 2. Competition, Unfair--Congresses. 3. Commercial law--

Congresses. I. Peitz, Martin, editor of compilation. II. Spiegel, Yossi, editor of compilation.

HF1414.A6235 2014

338.6'048--dc23

2014014496

\section{British Library Cataloguing-in-Publication Data}

A catalogue record for this book is available from the British Library.

Copyright (C) 2014 by Martin Peitz and Yossi Spiegel

All rights reserved.

In-house Editors: Sandhya Venkatesh/Chitralekha Elumalai

Typeset by Stallion Press

Email: enquiries@stallionpress.com 


\section{Contents}

About the Editors $\quad$ ix

About the Contributors $\quad$ xi

Introduction $\quad \mathbf{X v}$

Martin Peitz and Yossi Spiegel

Part I: Competition $\quad 1$

Chapter 1 Market Consolidation and Pricing

Developments in Grocery Retailing:

A Case Study 3

Ratula Chakraborty, Paul W. Dobson, Jonathan S. Seaton and Michael Waterson

Chapter 2 The Price Effects of Mergers in Airline Networks

Kai Hüschelrath and Kathrin Müller

Chapter 3 Pattern Asymmetry in the Pass-Through of Input Price Shocks in the Road Fuels Sector:

New Evidence on the United Kingdom

Enrico Pesaresi, Conor Flanagan

and Boryana Miteva

Chapter 4 Better Product at Same Cost: Leader Innovation

vs. Generic Product Improvement

David J. Balan and George Deltas 
Chapter 5 Industry Structure and Pricing Over

the Business Cycle

Yossi Spiegel and Konrad Stahl

Chapter 6 Price Competition between Platforms:

The Case of eBay vs. Yahoo! Auctions

Stefan Behringer

Part II: Anticompetitive Practices

173

Chapter 7 Cartel Sales Dynamics when Monitoring for Compliance is More Frequent than Punishment for Non-Compliance

Joseph E. Harrington, Jr. and Juan-Pablo Montero

Chapter 8 Exploitation and Induced Tacit Collusion:

A Classroom Experiment of Corporate

Leniency Programs

193

Jeroen Hinloopen and Adriaan R. Soetevent

Chapter 9 Quantity Discounts and Market Power:

The Michelin Case Revisited

Liliane Giardino-Karlinger

Chapter 10 Technology Transfer, Contracting, and Product

Market Competition

Frago Kourandi, Sabina Sachtachtinskagia

and Nikolaos Vettas

\section{Part III: Competition Policy and Regulation}

Chapter 11 How Can Competition Policy and Competition-Policy Economics Contribute to Solving the Healthcare Crisis? 
Chapter 12 Regulation Mismatch in Tackling $\mathrm{CO}_{2}$ Emissions Claude Crampes

Chapter 13 Public Policies in Investment-Intensive Industries Giovanni Immordino and Michele Polo

Chapter 14 The Role of Legal Principles in the Economic Analysis of Competition Policy

Harold Houba, Evgenia Motchenkova and Quan Wen

Chapter 15 Deterrence in Competition Law

Paolo Buccirossi, Lorenzo Ciari, Tomaso Duso, Giancarlo Spagnolo and Cristiana Vitale

Chapter 16 The Risks and Tricks in Public-Private Partnerships 455 Elisabetta Iossa, Giancarlo Spagnolo and Mercedes Vellez

Index 
This page intentionally left blank 


\section{About the Editors}

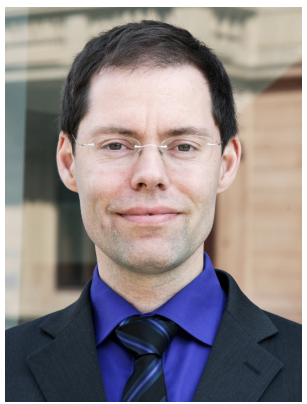

Martin Peitz is a Professor of Economics at the University of Mannheim (since 2007), a Director of the Mannheim Centre for Competition and Innovation - MaCCI (since 2009), an Academic Director of the Centre on Regulation in Europe, CERRE (since 2012), and a member of the economic advisory group on competition policy (EAGCP) at the European Commission (since 2013).

Martin Peitz is Editor of Review of Network Economics, Co-Editor of International Journal of Industrial Organization, Associate Editor of Journal of Industrial Economics, and Information Economics and Policy, and member of the editorial boards of Telecommunications Policy and Journal of Media Economics. He is Research Fellow of CEPR, CESifo and ENCORE, CRESSEAssociate, and ZEW Research Associate. He has widely published in leading economics journals. He is author of the books Industrial Organization: Markets and Strategies (with Paul Belleflamme) and Regulation and Entry into Telecommunications Markets (with Paul de Bijl), both published by Cambridge University Press, and editor of the Oxford Handbook of the Digital Economy (with Joel Waldfogel), published by Oxford University Press. His research covers various topics in industrial organization, competition policy, regulation, and microeconomics. 


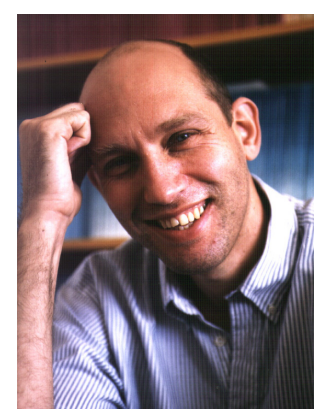

Yossi Spiegel is a Full Professor at the Recanati School of Business of Tel Aviv University and a Research Fellow at the CEPR and ZEW. His fields of research include Industrial Organization, Economics of Regulation and Antitrust, and Corporate Finance. He holds a $\mathrm{PhD}$ in Economics from Northwestern University (1991), MA in Economics from Tel Aviv University (1987), and BA in Economics and Accounting from Tel Aviv University (1985). Before joining Tel Aviv University, he was a member of technical staff at the Economics Research Group at Bell Communication Research for three years. He is a Co-editor of the International Journal of Industrial Organization, Journal of Economics and Management Strategy, and Foundations and Trends. For complete CV, see http://www.tau.ac.il/ $\sim$ spiegel. 


\title{
About the Contributors
}

\author{
David J. Balan \\ Bureau of Economics, Federal Trade Commission \\ dbalan@ftc.gov
}

\section{Stefan Behringer}

Universität Duisburg-Essen

stefan.behringer@uni-due.de

www.stefanbehringer.com

\section{Paolo Buccirossi}

Laboratorio di economia, antitrust e regolamentazione paolo.buccirossi@learlab.com

\section{Ratula Chakraborty}

University of East Anglia

r.chakraborty@uea.ac.uk

\section{Lorenzo Ciari}

European Bank for Reconstruction and Development ciaril@ebrd.com

lorenzociari@hotmail.com

\section{Claude Crampes}

Toulouse School of Economics

Claude.Crampes@tse-fr.eu

\section{George Deltas}

University of Illinois at Urbana-Champaign

deltas@illinois.edu 


\section{Paul W. Dobson}

University of East Anglia

p.dobson@uea.ac.uk

\section{Tomaso Duso}

-DIW and DICE

TDuso@diw.de

\section{Conor Flanagan}

Competition and Markets Authority

conor.flanagan@cma.gsi.gov.uk

\section{Liliane Giardino-Karlinger \\ Università LUISS Guido Carli \\ lilianegk@gmail.com}

Joseph E. Harrington, Jr.

The Wharton School of the University of Pennsylvania

harrij@wharton.upenn.edu

\section{Jeroen Hinloopen}

University of Amsterdam

J.Hinloopen@uva.nl

\section{Harold Houba}

$V U$ University

hhouba@feweb.vu.nl

\section{Kai Hüschelrath}

ZEW, MaCCI, and University of Mannheim

hueschelrath@zew.de

\section{Giovanni Immordino}

University of Salerno

giimmo@tin.it

\section{Elisabetta Iossa}

University of Rome Tor Vergata, CEPR and IEFE-Bocconi Elisabetta.Iossa@uniroma2.it 


\section{Michael L. Katz}

University of California

katz@haas.berkeley.edu

\section{Frago Kourandi}

Athens University of Economics and Business

kourandi@aueb.gr

\section{Boryana Miteva}

Expedia Affiliate Network

bmiteva@expedia.com

\section{Juan-Pablo Montero}

Pontificia Universidad Católica de Chile

jmontero@uc.cl

\section{Evgenia Motchenkova}

$V U$ University

emotchenkova@feweb.vu.nl

\section{Kathrin Müller}

ZEW and MaCCI

kathrin.mueller@zew.de

\section{Enrico Pesaresi}

European Commission, Directorate General for Competition enrico.pesaresi@ec.europa.eu

\section{Michele Polo}

Bocconi University and IEFE

michele.polo@unibocconi.it

\section{Sabina Sachtachtinskagia}

Athens University of Economics and Business

sabina@aueb.gr

\section{Jonathan S. Seaton}

Loughborough University

j.s.seaton@Lboro.ac.uk 


\section{Giancarlo Spagnolo}

University of Rome Tor Vergata, SITE-Stockholm, and CEPR

Giancarlo.Spagnolo@uniroma2.it

Giancarlo.Spagnolo@hhs.se

\section{Yossi Spiegel}

Tel Aviv University, CEPR, and ZEW

spiegel@post.tau.ac.il

\section{Konrad Stahl}

Universität Mannheim, CEPR, CESifo, and ZEW

kos@econ.uni-mannheim.de

\section{Adriaan Soetevent}

University of Groningen

A.R.Soetevent@rug.nl

\section{Mercedes Vellez}

University of Rome Tor Vergata and CEDES

mervellez@yahoo.com.ar

\section{Nikolaos Vettas}

Athens University of Economics and Business and CEPR

nvettas@aueb.gr

\section{Cristiana Vitale}

Organisation for Economic Cooperation and Development (Paris)

Cristiana.VITALE@oecd.org

\section{Michael Waterson}

University of Warwick

michael.waterson@warwick.ac.uk

\section{Quan Wen}

University of Washington

wenq2@u.washington.edu 


\section{Introduction}

The Competition and Regulation European Summer School and Conference (CRESSE) is an informal network of academics and professionals with an interest in Competition Policy and Sectoral Regulation. It was initiated by Yannis Katsoulacos (Athens University of Economics and Business) in 2005. The annual conference organized by CRESSE has since grown to become an important event in the competition and regulation conferences calendar. The objective is to provide a forum in which the latest research in the areas of competition and regulation is presented and discussed. Presentations in the three-day annual conference include several invited papers and a selection of papers that were submitted in response to a call for papers in major IO journals and the Conference web site (www.cresse.info). The annual CRESSE Conference is organized in early July in Greece; the institution responsible for the organization is the Athens University of Economics and Business.

CRESSE also organizes an annual Summer School in which Visiting Faculty from a number of European and U.S. Universities provide high-quality training to practitioners of competition policy and sectoral regulation that wish to be acquainted with the most recent economic and legal developments. It is also active in disseminating research in the areas of competition policy and regulation and in contributing through the organization of special policy sessions and roundtables that deliver public debates on topical policy issues.

This volume contains some of the papers that were presented at the 2012 CRESSE Conferences which was held in Chania, Crete, on July 6-8, 2012, and the 2013 CRESSE Conferences which was held in Corfu on 
July 5-7, 2013. We are grateful to several colleagues who were generous to help us evaluating the papers for the volume and provided authors with constructive comments and suggestions.

We have grouped the chapters in three parts. Part I contains chapters that examine various aspects of competition. The first three chapters are empirical contributions. Of these, the first two consider price effects of mergers in grocery retailing (Chakraborty et al.) and in airlines (Hüschelrath and Müller), while the third (Pesaresi et al.) focuses on cost pass-through in the road fuel sector. The other three chapters in Part I of the book are theoretical contributions and they address the effect of innovation on sales and consumer surplus (Balan and Deltas), the effect of demand fluctuations on prices, price-cost margin entry, and capacity utilization (Spiegel and Stahl), and the effect of endogenous seller charges on platform competition (Behringer).

Part II contains chapters on anticompetitive practices. The first two address horizontal practices: cartels (Harrington and Montero) and tacit collusion (Hinloopen and Soetevent). The remaining two chapters address vertical exclusionary practices: Quantity and loyalty discounts (GiardinoKarlinger) and technology transfers (Kourandi et al.).

Finally, Part III of the book contains chapters on competition policy and on regulation. The two first chapters elaborate on two key policy issues, health care (Katz) and regulations of $\mathrm{CO}_{2}$ emissions (Crampes). Both chapters look at these public policy issues from an industrial organization perspective. The other four chapters in Part III of the book study a number of general policy issues, including public policies in innovative industries (Immordino and Polo), the role of legal principle in competition economics (Houba et al.), deterrence in competition law (Buccirossi et al.), and various problems in the design of public-private partnership contracts (Iossa et al.)

The chapters in this volume are at the frontier of empirical or theoretical research on competition issues and they either contain original research, or put recent research into perspective. Each chapter is preceded by a short abstract. 